\title{
The Impact of Polluting Sources on the Physical- Chemical Properties of Water in the Curved River in Kosovo
}

\author{
Sadija Kadriu $^{1 *}$, Milaim Sadiku ${ }^{1}$, Mensur Kelmendi ${ }^{1}$, Agron Shala ${ }^{2}$ \\ ${ }^{1}$ Faculty of Food Technology, Department of Technology, University of Mitrovica, 40000, Mitrovica, Kosovo \\ ${ }^{2}$ Hydro-meteorological Institute of Kosova, Rruga Lidhja e Pejës 47, 10000, Prishtinë, Kosova
}

Received: 16/10/2020 Accepted: 11/12/2020_ Published: 20/06/2021

\begin{abstract}
It has already become a tradition to research the pollution with heavy metals of surface and groundwater. Very few studies have been done to assess the ecological status of rivers in Kosovo, based on their assessment through physical-chemical parameters, such as: $\mathrm{pH}$, OT, $\mathrm{BOD}_{5}, \mathrm{COD}, \mathrm{N}-\mathrm{NH}_{4}, \mathrm{NO}_{3}{ }^{-}, \mathrm{NT}, \mathrm{PO}_{4}-\mathrm{P}, \mathrm{PT}$. Although it is known that physical-chemical pollution of surface water is present in the flow of rivers, since in the impossibility of setting up plants for the treatment of industrial and urban wastewater, in all cases their discharge is done in a way free and uncontrolled. Therefore, our object of study consists in the real evidence of physical-chemical pollution of the waters of the Curved River (Kriva Reka), a segment of which crosses the industrial area of the Artana Mine, located in the northeastern part of Kosovo. During the research work we have identified six monitoring points: $\mathbf{M}_{1}$ and $\mathrm{M}_{6}$ represent the river waters outside the industrial zone, while the other four monitoring points reflect the industrial discharge waters and the polluted river waters in the industrial zone. Classical and instrumental methods of analytical chemistry have been applied to determine physical-chemical parameters. The results obtained after the analysis of water samples give the values of physical-chemical parameters, based on which we estimate that the Curved River is characterized by poor ecological status.
\end{abstract}

Keywords: Curved River, Pollution, Physical-chemical parameters, Ecological status, Mining

\section{Introduction}

Water in nature is important for the existence and health of humans and all other living beings, because it mediates the global processes of life, transports substances and helps to carry out chemical reactions. In addition, water enables man to produce food, energy, transportation, and as a raw material or auxiliary raw material, participates in a number of industrial processes. This is why in recent decades, water quality is of global interest, going beyond the competencies of the experts themselves in this field and encompassing all spheres of economic, legal and political life, and increasingly gaining an international dimension (1-2). The Curved River, better known as Kriva Reka on topographic maps, is the left tributary of the Morava e Binçës and lies in the northeastern part of Anamorava, east of Kosovo. The total area of the basins of this river is $612.5 \mathrm{~km} 2$, while the river has a length of $75 \mathrm{~km}$. The basin of this river includes many other tributaries which are short and have a small amount of water, but the permanent suppliers are the inflows from the rivers Hogosht and Desivojce. The river bed has formed a narrow alluvial valley, while in the suburbs of Kamenica it passes through a plain terrain and during the rainy season (spring, winter and autumn), there are cases when it has caused flooding of agricultural lands, which extend on both sides of river banks.

The watershed up to Kamenica is forested, while part of the lowland is used as agricultural land by the population living on both sides of the river banks. Mountainous relief, slope of the terrain and the impact of rainfall on erosion, not only affect the water quality of this river, but also increase and decrease the volume according to the seasons. According to data and measurements made in the village of Domoroc by MESP (Ministry of Environment and Spatial Planning), the highest river water level reaches $400 \mathrm{~cm}$, while the lowest $140 \mathrm{~cm}$, so the amplitude is $540 \mathrm{~cm}$. This river intersects two streams where the water at the first monitoring point results in high quality, while at the second station in Domorove the water quality drops (3). In addition to natural factors, anthropogenic factors also have a significant impact on the water quality of this river. Immediately after the constitution of Trepça combine with the aim of achieving the most underground mineral resources, it emerged as a necessity opening of galleries rich with heavy metals (4). Exploitation and processing of minerals, apart from economic development, resulted in the pollution of the environment (5).The existence and industrial activity of the Artana Mine (Novobrdë), located near

*Corresponding author: Sadija Kadriu, Faculty of Food Technology, Department of Technology, University of Mitrovica, 40000, Mitrovica, Kosovo. E-mail: sadija.kadriu@umib.net 
the eastern part of the river, which is, which in the past was known as the mine of gold and silver and other heavy metals, with all its complexity is the main polluter of the River Curved (Kriva Reka). Numerous historical chronicles document that the opening and exploitation of this mine began in the time of the Roman Empire. It began to be used more intensively in the medieval period, first by the Ragusans (Dubrovnik), then by the German Sassanids, while at the beginning of June 1455 it was conquered and taken into use by the Ottoman Empire (6). Mining by its nature consumes, diverts and can seriously pollute water resources (7). Therefore, the mining activity near the Curved River has motivated us to research and assess the ecological status of its waters, focusing on physical-chemical parameters. Indiscriminate industrial discharges from the mine and flotation, which flow into the river through a stream, as well as the existence of two landfills with industrial waste on the banks of the river, have constantly caused and continue to cause pollution of the waters of this river. A variety of pollutants are generated in the process of ore mining which diffuse into the surrounding environment and result in water, air and soil pollution problems (8).

\section{Curved River water monitoring}

In order to have a more representative overview of the ecological status of the waters of the Curved River (Kriva Reka), we focused on the degree of pollution of this river, based on physical-chemical parameters. Testing of all chemical indicators of water quality is very rarely justified for economic and practical reasons, so in practice only a few characteristics are tested that give a general answer to the question of water quality, ie indicate in which direction Research is ongoing. Currently, there are various models for determining surface water quality (9), in order to simplify and reduce the cost of testing. However, we must realize that this is a complex task and that there is no uniform algorithm to work with (10-12). It is already known that the waters of this river since the ' $50 / 60$ s have been the prey of industrial discharges made without any criteria by the administration of the Artana (Novo Brdo) mine. Precisely for this reason, and based on the visual observation, where the lack of living world was clearly observed, we came up with the idea to research and analyze the degree of pollution of the waters of this river through physical-chemical parameters. The interactions of both the physical and chemical properties of water play a significant role in composition, distribution, abundance, movements and diversity of aquatic organisms (13-17).During the research we managed to find enormous pollution of these waters, not only with heavy metals, which occur as a result of industrial discharges, but also significant physical-chemical pollution. Therefore, for this reason we targeted six monitoring points: $M_{1}$ and $\mathrm{M}_{6}$ represent the points located outside the industrial area of the Artana mine, while $\mathrm{M}_{2}, \mathrm{M}_{3}, \mathrm{M}_{4}$ and $\mathrm{M}_{5}$, reflect the monitoring points within the industrial area. The coordinates in table 1. Reflect the six sampling sites, while figures 1 and 2 reflect the monitoring grid.

Figure 1 reflects the entire monitoring network, four sampling sites located within the industrial area of the Artana mine $\left(\mathrm{M}_{2}\right.$, $\mathrm{M}_{3}, \mathrm{M}_{4}$ and $\mathrm{M}_{5}$ ) and two sampling sites outside the industrial area ( $\mathrm{M}_{1}$ and $\left.\mathrm{M}_{6}\right)$. Figure 2 shows the monitoring network within the industrial area, so sampling sites: $\mathbf{M}_{2}, \mathbf{M}_{3}, \mathbf{M}_{4}$ and $\mathbf{M}_{5}$. Sampling site $M_{1}$ - represents the Curved River (Kriva Reka) before the discharge of mine waters. In this sampling site we have detected the waters of the Curved River in front of the industrial area of the Artana mine (fig.3), where the water, apart from urban pollution, should have no other pollution.

$\mathrm{M}_{2}$ - Pollution from mine discharges: This sampling site reflects the critical place where the enormous and indiscriminate discharge of mine and flotation waters takes place (fig.4), which through a stream was thrown into the waters of the Curved River.

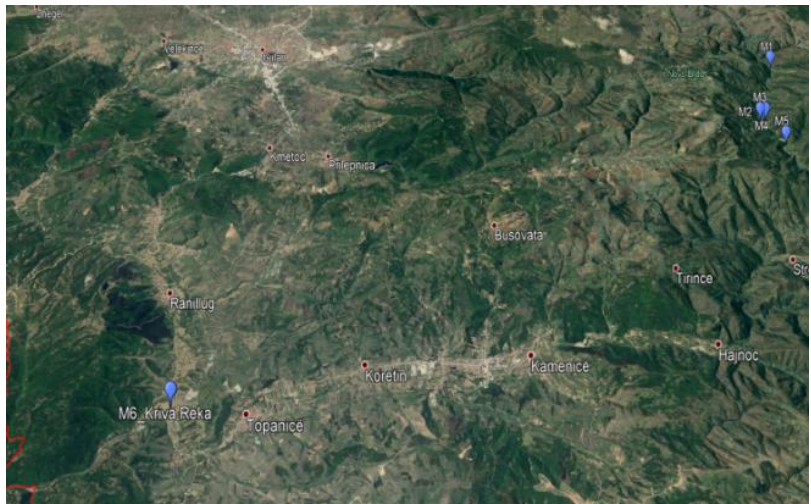

Figure 1: Complete monitoring network

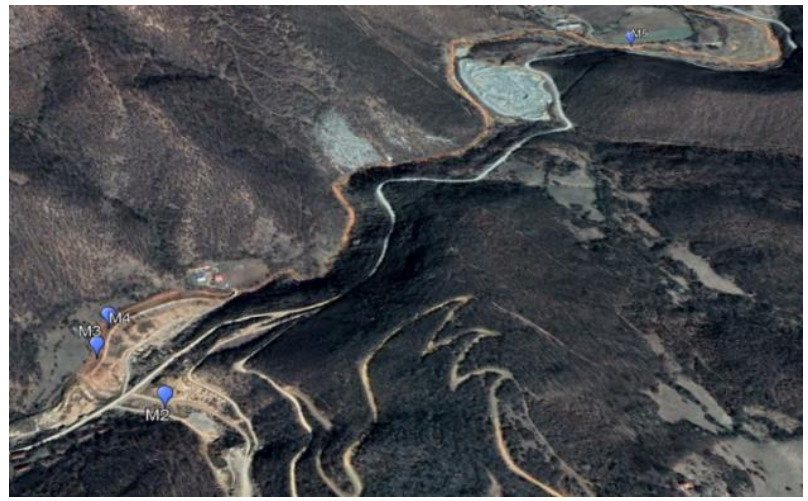

Figure 2: Monitoring network in the Artana area

Table 1: Sampling site and their coordinates

\begin{tabular}{cccc}
\hline Sampling site & Geographical width & Longitude & Altitude (m) \\
\hline M1 & $42^{\circ} 38^{\prime} 1.57^{\prime \prime N}$ & $21^{\circ} 23^{\prime} 35.35^{\prime \prime} \mathrm{E}$ & 699 \\
M2 & $42^{\circ} 37^{\prime} 58.78^{\prime \prime} \mathrm{N}$ & $21^{\circ} 25^{\prime} 48.41^{\prime \prime} \mathrm{E}$ & 664 \\
M3 & $42^{\circ} 38^{\prime} 2.79^{\prime \prime} \mathrm{N}$ & $21^{\circ} 25^{\prime} 44.07^{\prime \prime} \mathrm{E}$ & 646 \\
M4 & $42^{\circ} 38^{\prime} 4.74^{\prime \prime} \mathrm{N}$ & $21^{\circ} 25^{\prime} 44.62^{\prime \prime} \mathrm{E}$ & 649 \\
M5 & $42^{\circ} 38^{\prime} 29.97 " \mathrm{~N}$ & $21^{\circ} 26^{\prime} 25.99^{\prime \prime} \mathrm{E}$ & 621 \\
M6 & $42^{\circ} 30^{\prime} 36.66^{\prime \prime} \mathrm{N}$ & $21^{\circ} 37^{\prime} 55.56^{\prime \prime} \mathrm{E}$ & 429 \\
\hline
\end{tabular}




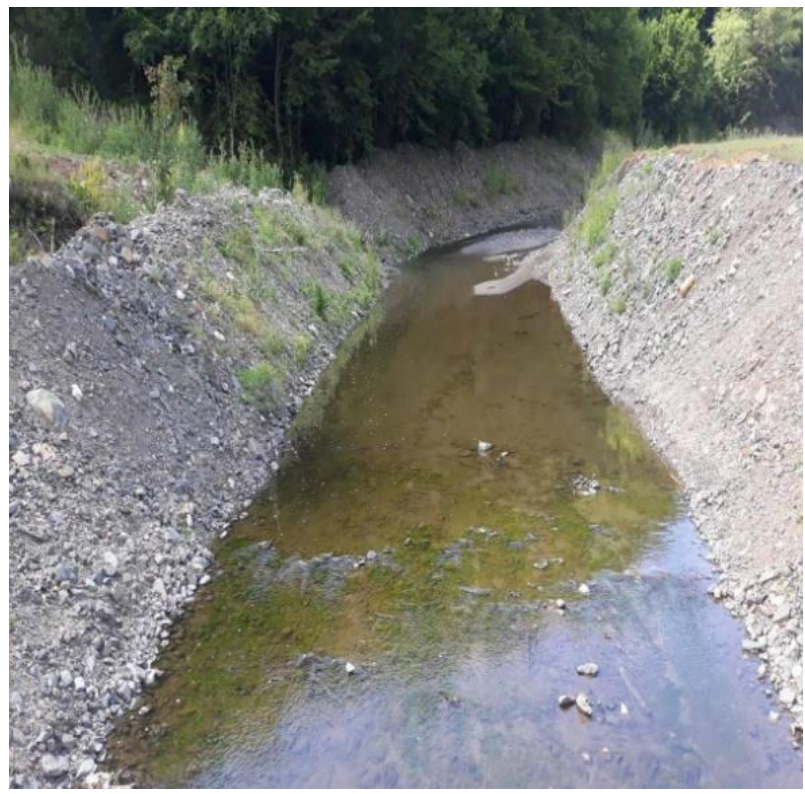

Figure 3: Sampling site $\mathrm{M}_{1}$

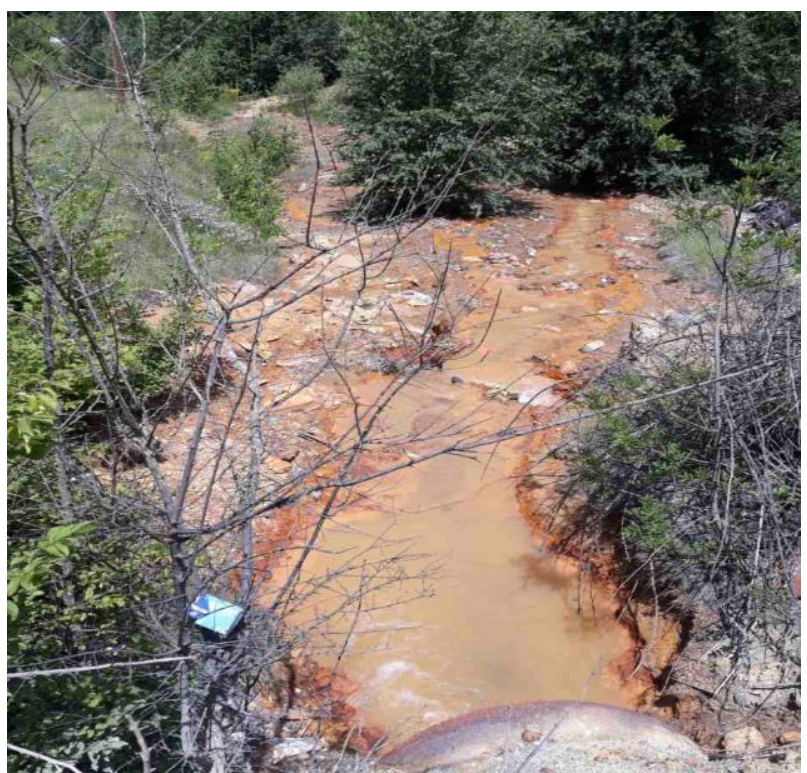

Figure 4: Sampling site $\mathrm{M}_{2}$

$\mathrm{M}_{3}$ - Curved River after mine discharges: The waters of this sampling site represent the sample taken after discharges from the mine and flotation (fig. 5).

$\mathrm{M}_{4}$ - Waters after the first landfill: We have targeted this sampling site to assess the pollution caused by the landfill drainage water (fig. 6).

M5 - Curved River after the second landfill: Sampling site M5 presents the state of water quality of the Curved River, after the drainage of the second landfill (fig.7). This landfill is located at a distance of $1.7 \mathrm{k} \mathrm{m}$ from the first landfill. Like the first landfill, the draining waters of this landfill only increase the degree of concentration of pollutants in the waters of this river. As a result of atmospheric processes such as precipitation, sunning and erosive winds, landfill generates contaminants that pollute the environment in cyclical (18).

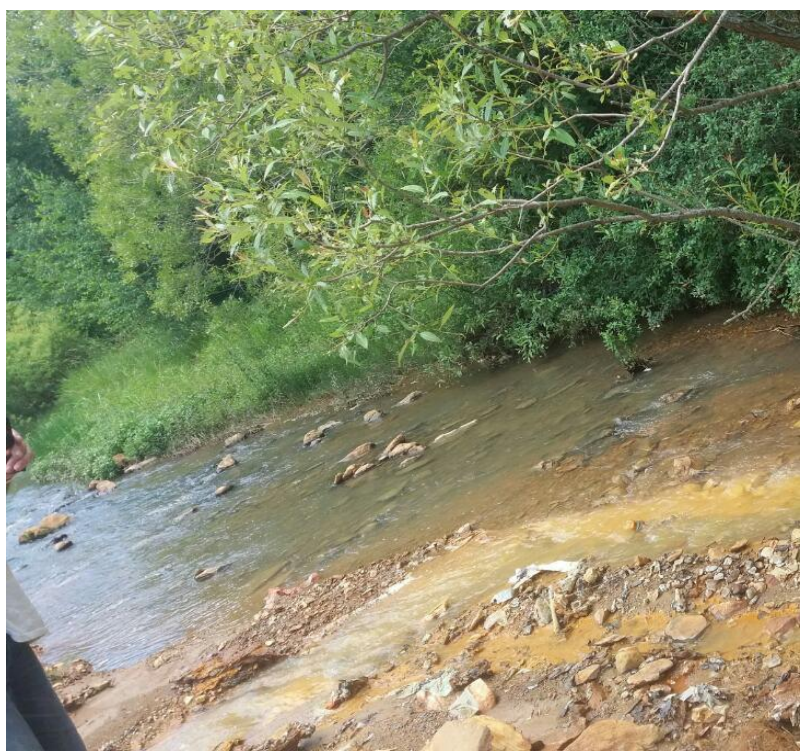

Figure 5: Sampling site $\vec{M}_{3}$

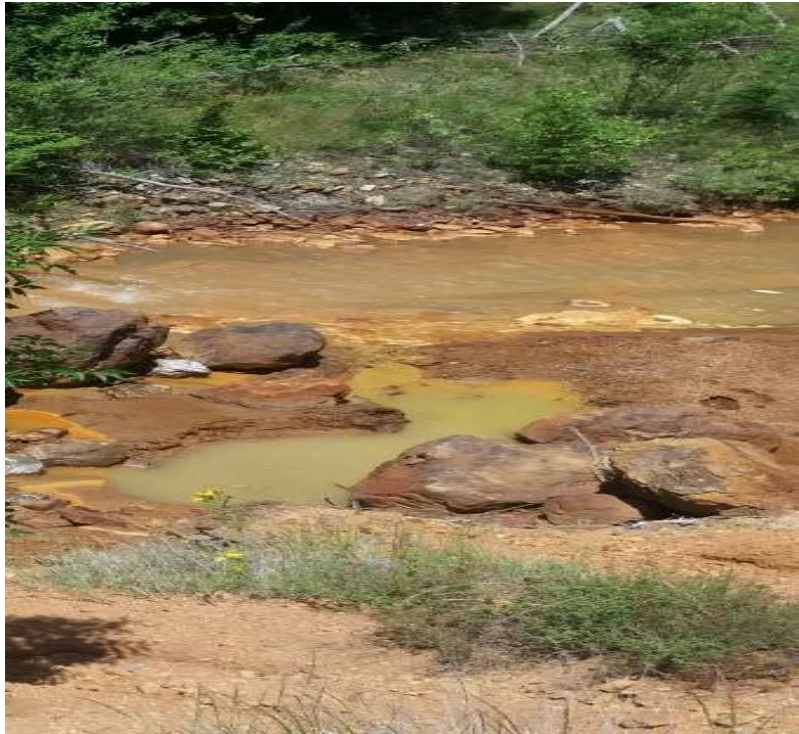

Figure 6: Sampling site $\mathrm{M}_{4}$

$\mathrm{M}_{6}$ - Curved river before joining the Morava e Binçës river: This sampling site represents the last monitoring point of the Curved River waters (fig.8). For the sake of a more realistic assessment, we took the sample $800 \mathrm{~m}$ before joining the Morava se Binçe River, which after joining the Waters River flows into the territory of Serbia. Therefore, this monitoring point gives us to understand that all waters belonging to this sub-basin are polluted by industrial, agricultural and urban sources. 


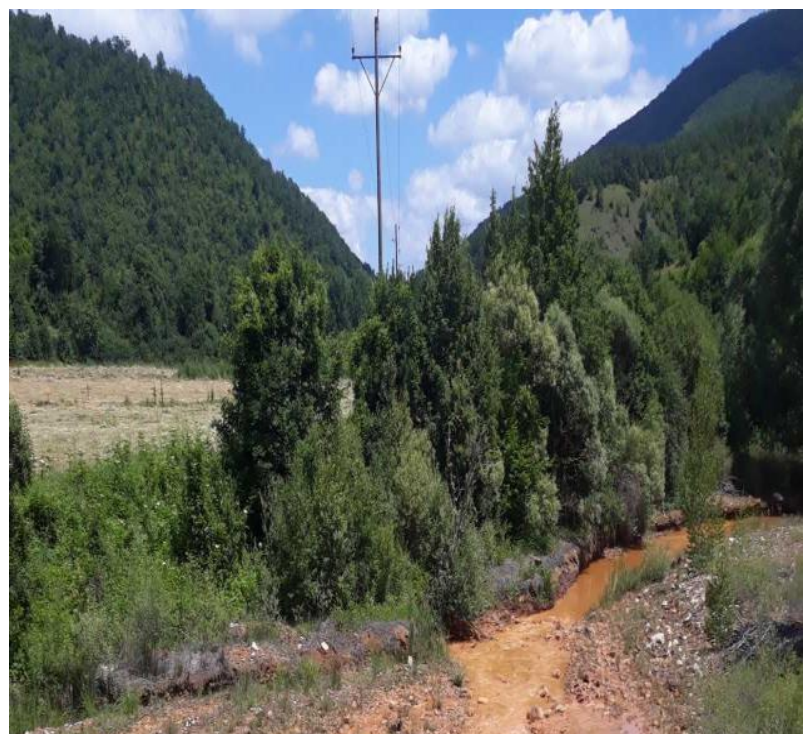

Figure 7: Sampling site $\mathbf{M}_{5}$

\section{Material and methods}

In order to be as accurate as possible in assessing the ecological status of waters taken for analysis from the Curved River (Kriva Reka), we are based on the ISO 5667-6 (19)standard for surface water. The way of taking water samples of this sub-basin, the quantity of the sample taken as well as the way of transport and the maximum time that the sample can stand before the chemical analysis, is done in accordance with the method ISO 5667-1,3 (20 - 21).

For the determination of physical-chemical parameters, in the analysis laboratory of KHMI (Kosovo Hydrometeorological Institute), we have applied the following methods: ISO 10523: 2008 (pH value); ISO 5814: 2012 (Dissolved oxygen OT); ISO 5815-2 (Biochemical Oxygen Consumption BOD 5 ); ISO 15705 (Chemical Oxygen Consumption COD); ISO 7150-1 (Ammonia $\mathrm{NH}_{4}-\mathrm{N}$ ); DIN 38405 D9 ( Nitrates $\mathrm{NO}_{3}^{-}$); ISO 11905-1 (Total
Nitrogen NT); ISO 6878 (Orthophosphate (PO4-P); ISO 6878 (Total Phosphorus PT).

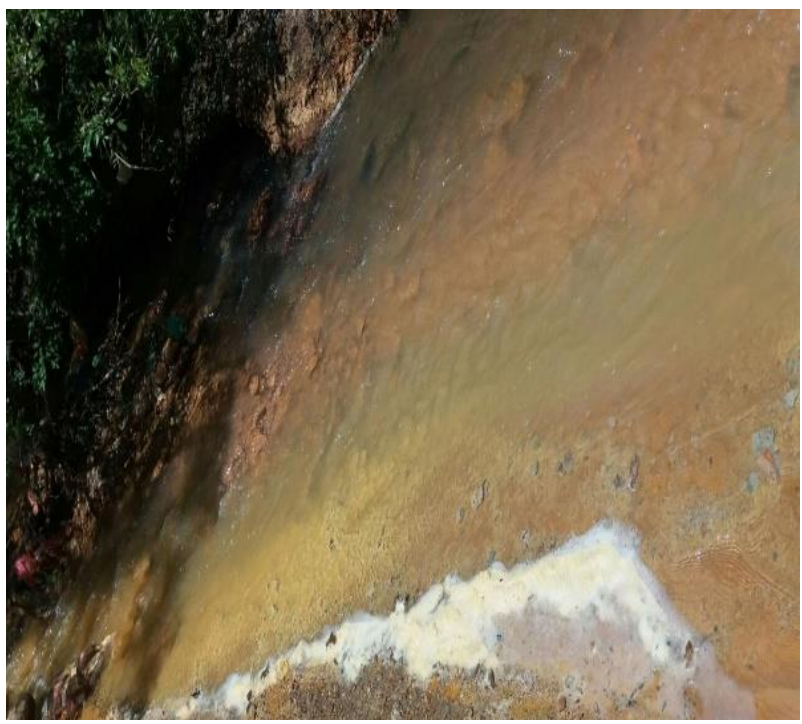

Figure 8: Sampling site $\mathrm{M}_{6}$

\section{Results and discussion}

For the purpose of better evaluation of the results obtained from the analysis of physical-chemical parameters, water samples for the analysis of the Curved River were taken during January and July 2020. In the focus of the research we have singled out: $\mathrm{pH}, \mathrm{OT}, \mathrm{BOD}, \mathrm{COD}, \mathrm{NH}_{4}-\mathrm{N}, \mathrm{NO}_{3}-\mathrm{NT}, \mathrm{PO}_{4}-\mathrm{P}, \mathrm{PT}$, which are the best indicators of the ecological status of rivers. The use of indicators is highly relevant when assessing the ecological status of a river bed and its evolution with time (22). For the evaluation of the researched parameters we have relied on the Administrative Instruction, which has to do with the Classification of Water and Surface Bodies of Kosovo - MESP-UA 16/2017 * (23) and based on appendix 4 and table 4.1 of this appendix, relating to parametric values for determining the ecological status of rivers (table 2).

Table 2: Physical-chemical parameters for determination of ecological status of rivers in $\mathrm{mg} / \mathrm{L}$

\begin{tabular}{ccccccccccc}
\hline Type* $^{*}$ & Status & $\mathrm{pH}$ & $\mathrm{OT}$ & $\mathrm{BOD}_{5}$ & $\mathrm{COD}$ & $\mathrm{NH}_{4}-\mathrm{N}$ & $\mathrm{NO}_{3}$ & $\mathrm{NT}$ & $\mathrm{P} 0_{4}-\mathrm{P}$ & $\mathrm{PT}$ \\
\hline & $\mathrm{G}$ & $7,0-8,6$ & $>8,0$ & $<1,50$ & $<4,0$ & $<0,10$ & $<1,50$ & $<2,0$ & $<0,05$ & $<0,09$ \\
$\mathrm{~T}_{1}$ & $\mathrm{Md}$ & $<7.0 ;>9.0$ & $8.0-7.0$ & $1.50-5.00$ & $4.0-7.0$ & $0.10-0.20$ & $1.50-3.00$ & $2.0-3.5$ & $0.05-0.10$ & $0.09-0.15$ \\
& $\mathrm{P}$ & $<7.0 ;>9.0$ & $7.0-5.0$ & $5.00-6.00$ & $7.0-12.0$ & $0.20-0.80$ & $3.00-6.00$ & $3.5-10.0$ & $0.10-0.20$ & $0.15-0.30$ \\
& $\mathrm{G}$ & $7.0-8,6$ & $>7.0$ & $<4.0$ & $<4.0$ & $<0.10$ & $<1.00$ & $<1.5$ & $<0.05$ & $<0.10$ \\
$\mathrm{~T}_{2}$ & $\mathrm{Md}$ & $<7.0>9.0$ & $7.0-6.0$ & $4.0-6.0$ & $4.0-7.0$ & $0.10-0.25$ & $1.00-2.00$ & $1.5-3.0$ & $0.05-0.10$ & $0.10-0.20$ \\
& $\mathrm{P}$ & $<7.0>9.0$ & $6.0-5.0$ & $6.0-8.0$ & $7.0-12.0$ & $0.25-0.70$ & $2.00-5.00$ & $3.0-10.0$ & $0.10-0.20$ & $0.20-0.40$ \\
\hline
\end{tabular}

MESP-AI 16/2017 * - Administrative Instruction "Classification of Surface Water Bodies"

Type * - $\mathrm{T}_{1}$ - Small Mountain River and Medium River; $\mathrm{T}_{2}$ - Meadow river: small, medium and large.

Status G-Good; Md-Moderate P-Poor/Weak 
Table 3 shows the ecological status of surface waters. Curved River belongs to the type of rivers $\mathrm{T}_{2}$ (Meadow river: small, medium and large). The obtained results marked in tables 4 and 5, are compared with the reference values of MESP-AI 16/2017 appendix 4 (table 2). Tabular results, also given through colors, reflect the state of water quality detected in six sampling sites. Samples $\mathrm{M}_{1}$ and M6 represent the water quality outside the industrial area of the Artana Mine, while $\mathbf{M}_{2}, \mathrm{M}_{3}, \mathrm{M}_{4}$ and $\mathrm{M}_{5}$ within the industrial area. In the $\mathrm{M}_{1}$ sampling sitein January we encountered poor $\mathrm{NO}_{3}$-status, while in July, due to higher temperatures and lower water volume, the indicators of $\mathrm{BOD}_{5}$, $\mathrm{COD}, \mathrm{NO}_{3}, \mathrm{NT}$ and PT, also reflect poor(weak) ecological status of the waters of this river(figure 9). The results obtained for January and July are presented in Tables 4 and 5 through colors. In the $\mathbf{M}_{2}$ sampling site, both for January and July (Figure 10), except OT, $\mathrm{NH}_{4}-\mathrm{N}, \mathrm{NO}_{3}{ }^{-}, \mathrm{NT}$, which belong to the good quality status, other indicators reflect the poor ecological status.

Table 3: Assessment of ecological status reflected in color

\begin{tabular}{ll|}
\hline Status assessment & Color \\
\hline High status & Blue \\
Good & Green \\
Moderate & Yellow \\
Poor/Weak & Orange \\
Bad status & Red \\
\hline
\end{tabular}

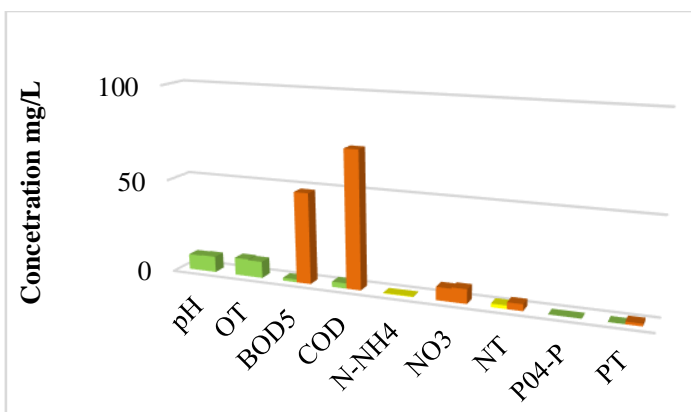

Physical-chemical parametres

Figure 9: Concetration of physical-chemical parameters in sampling site $\mathrm{M}_{1}$ (January and July, 2020)

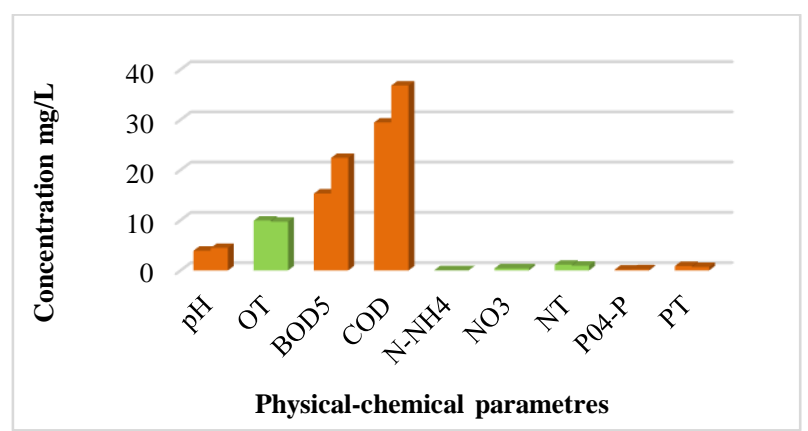

Figure 10: Concetration of physical-chemical parameters in sampling site $\mathbf{M}_{2}$ (january and july, 2020)

Table 4: Results of physical-chemical parameters (mg/L) for the assessment of the ecological status of the Curved River (January 2020)

\begin{tabular}{ccccccccccc}
\hline Sampling site & $\mathrm{pH}$ & $\mathrm{OT}$ & $\mathrm{BOD} 5$ & $\mathrm{COD}$ & $\mathrm{NH}_{4}-\mathrm{N}$ & $\mathrm{NO}_{3}$ & $\mathrm{NT}$ & $\mathrm{P} 0_{4}-\mathrm{P}$ & $\mathrm{PT}$ & Final Classification \\
\hline $\mathrm{M}_{1}$ & 8.20 & 9.25 & 1.5 & 2.80 & 0.217 & 6.90 & 1.840 & 0.016 & 0.082 & $\mathrm{P}$ \\
$\mathrm{M}_{2}$ & 3.92 & 9.92 & 15.3 & 29.44 & 0.025 & 0.4 & 1.13 & 0.163 & 0.861 & $\mathrm{P}$ \\
$\mathrm{M}_{3}$ & 5.93 & 9.12 & 24.4 & 55.2 & 0.209 & 6.7 & 3.53 & 0.025 & 1.551 & $\mathrm{P}$ \\
$\mathrm{M}_{4}$ & 4.88 & 3.4 & 23.5 & 97.6 & 0.101 & 2.1 & 7.54 & 1.82 & 3.144 & $\mathrm{P}$ \\
$\mathrm{M}_{5}$ & 6.97 & 9.58 & 25.1 & 56.8 & 0.189 & 6.5 & 3.63 & 0.040 & 1.599 & $\mathrm{P}$ \\
$\mathrm{M}_{6}$ & 7.89 & 8.48 & 27.2 & 65.0 & 1.185 & 5.5 & 4.440 & 0.051 & 1.830 & $\mathrm{P}$ \\
\hline
\end{tabular}

Table 5: Results of physical-chemical parameters (mg/L) for the assessment of the ecological status of the Curved River (July 2020)

\begin{tabular}{ccccccccccc}
\hline Sampling site & $\mathrm{pH}$ & $\mathrm{OT}$ & $\mathrm{BOD}_{5}$ & $\mathrm{COD}$ & $\mathrm{NH}_{4}-\mathrm{N}$ & $\mathrm{NO}_{3}$ & $\mathrm{NT}$ & $\mathrm{P} 0_{4}-\mathrm{P}$ & $\mathrm{PT}$ & Final Classification \\
\hline $\mathrm{M}_{1}$ & 8.47 & 8.8 & 48.2 & 72.8 & 0.258 & 7.6 & 3.53 & 0.028 & 1.36 & $\mathrm{P}$ \\
$\mathrm{M}_{2}$ & 4.47 & 9.7 & 22.4 & 36.8 & 0.031 & 0.4 & 0.94 & 0.218 & 0.69 & $\mathrm{P}$ \\
$\mathrm{M}_{3}$ & 5.81 & 8.3 & 41.5 & 69 & 0.224 & 7.2 & 3.22 & 0.033 & 1.17 & $\mathrm{P}$ \\
$\mathrm{M}_{4}$ & 5.21 & 1.2 & 69.3 & 122 & 0.111 & 2.3 & 9.28 & 2.429 & 2.73 & $\mathrm{P}$ \\
$\mathrm{M}_{5}$ & 6.85 & 7.6 & 42.9 & 71 & 0.212 & 7.1 & 3.34 & 0.051 & 1.22 & $\mathrm{P}$ \\
$\mathrm{M}_{6}$ & 7.45 & 6.57 & 43.4 & 69 & 2.075 & 6.1 & 4.63 & 0.068 & 1.27 & $\mathrm{P}$ \\
\hline
\end{tabular}


Sampling site $\mathrm{M}_{3}$, except $\mathrm{NH}_{4}-\mathrm{N}$, OT and $\mathrm{PO}_{4}-\mathrm{P}$ which present good and moderate status, other indicators reflect the poor ecological status of these waters (figure 11). $\mathbf{M}_{4}$ represents the sampling site, where in addition to $\mathrm{NH}_{4}-\mathrm{N}$, with good status, other indicators, for both months (figure 12), reflect poor status for water quality.

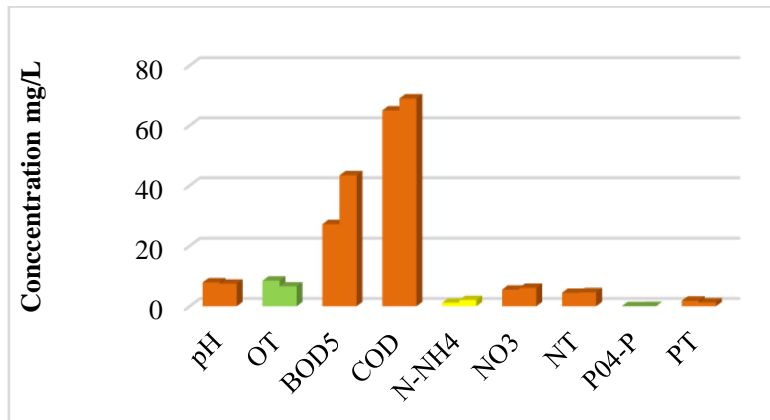

Physical-chemical parametres

Figure 11: Concetration of physical-chemical parameters in sampling site $\mathrm{M}_{3}$ (January and July, 2020)

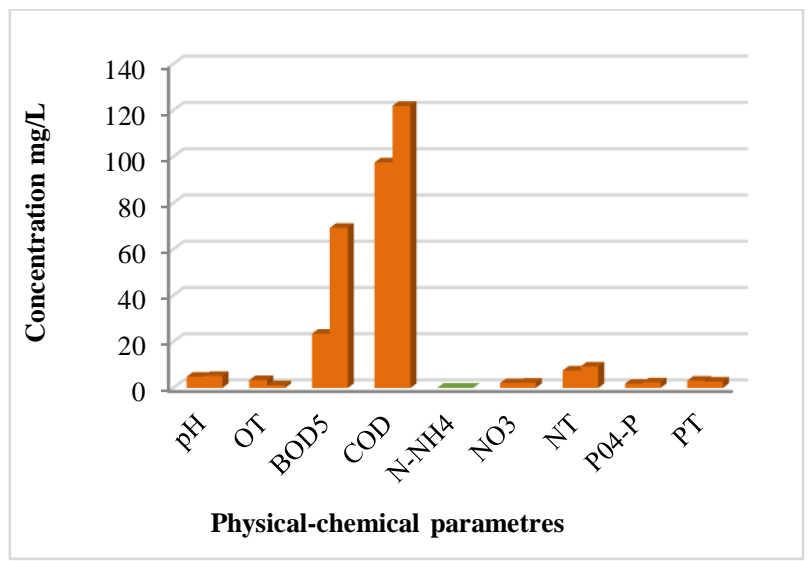

Figure 12: Concetration of physical-chemical parameters in sampling site $\mathrm{M}_{4}$ (January and July, 2020)

In the $\mathrm{M}_{5}$ remote sampling with good quality status, $\mathrm{NH}_{4}-\mathrm{N}$ was found, moderate OT and $\mathrm{PO}_{4}-\mathrm{P}$, while other indicators for these waters, result in poor quality. The analyzes of the values obtained and reflected in tabular way (tables 4 and 5), prove that in all sampling sites, we have encountered poor $(\mathrm{P})$ ecological status of the waters of this river. Sampling site $\mathrm{M}_{6}$, for two months, presents good condition for $\mathrm{pH}$ and $\mathrm{PO}_{4}-\mathrm{P}$, moderate with OT, while other indicators (figure 14), result in poor ecological status of the water quality of the Curved River.

\section{Conclusion}

Based on the Administrative Instruction of Kosovo MESP-AI $16 / 2017$, which deals with the Classification of Water and Surface Bodies and the parametric values for determining the ecological status of rivers, we conclude that the quality of water of the Curved River, monitored during the months January and July, 2020, has resulted in significant pollution. Poor ecological status has occurred as a result of mining and processing within the industrial zone $\left(\mathrm{M}_{2}, \mathrm{M}_{3}, \mathrm{M}_{4}\right.$ and $\left.\mathrm{M}_{5}\right)$, while the sampling site $\mathrm{M}_{6}$, in addition to industrial pollution, includes agricultural and urban pollution. Therefore, the lack of living world in the monitored area, best reflects the state of poor water quality of this river. This pollution should raise the awareness of the mine management, the governing bodies of the municipalities (through whose territory the river passes), and the Ministry of Environment and Spatial Planning of Kosovo, to take appropriate measures to remove the pollutants of the Curved River.

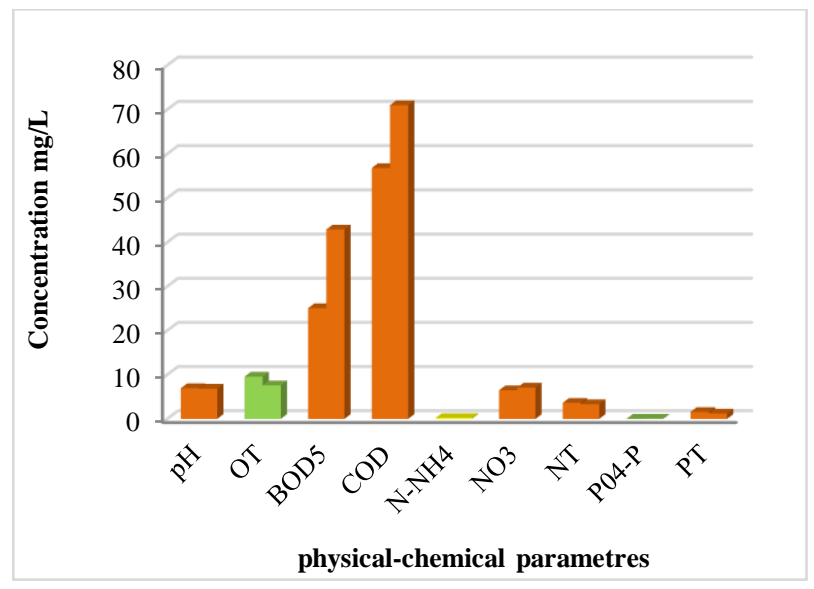

Figure 13: Concetration of physical-chemical parameters in sampling site $\mathrm{M}_{5}$ (January and July, 2020)

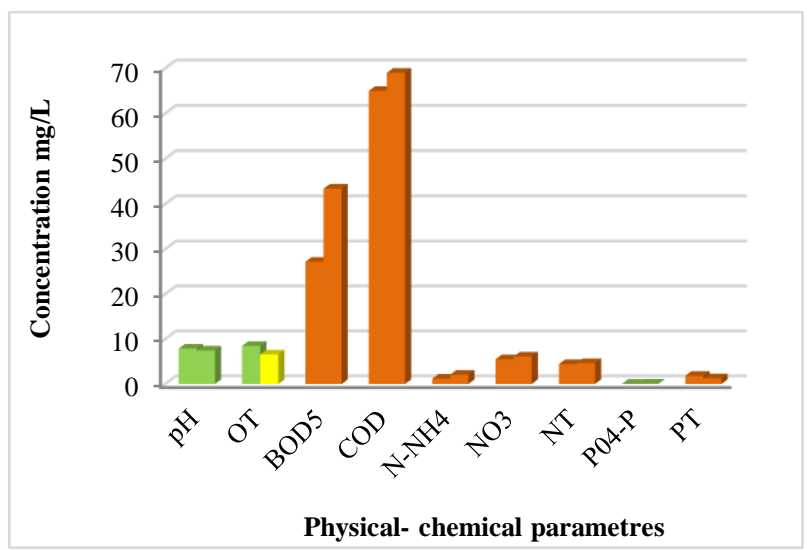

Figure 14: Concetration of physical-chemical parameters in sampling site $\mathrm{M}_{6}$ (January and July, 2020)

\section{Aknowledgment}

For the successful realization of the experimental part of this work, we thank the staff of the laboratory of the Hydrometeorological Institute of Kosovo. Special thanks also to your editorial staff, for the opportunity provided and for cooperation in publishing this paper.

\section{Ethical issue}

Authors are aware of, and comply with, best practice in publication ethics specifically with regard to authorship (avoidance of guest authorship), dual submission, manipulation of figures, competing interests and compliance with policies on research ethics. Authors adhere to publication requirements that 
submitted work is original and has not been published elsewhere in any language.

\section{Competing interests}

The authors declare that there is no conflict of interest that would prejudice the impartiality of this scientific work.

\section{Authors' contribution}

All authors of this study have a complete contribution for data collection, data analyses and manuscript writing

\section{References}

1. Biswas AK. Integrated water resources management: Is it working? Water resources development. 2008; 24(1): 5-22.

2. Vučijak B, Ćerić A, Silajdžić I, Midžić Kurtagić S. Voda za život: Osnove integralnog upravljanja vodnim resursima. Institut za hidrotehniku Građevinskog fakulteta u Sarajevu d.d. Sarajevo. 2011; 8: 1-148.

3. Raport për gjendjen e ujërave në Republikën e Kosovës. Agjencioni për Mbrojtjen e Mjedisit të Kosovës. Prishtinë. 2015.

4. Kadriu S, Aliu M, Sadiku M, Kelmendi M, Mulliqi I, Hajdini S. The Pollution of River Trepça with Heavy Metals as a Result of Exploitation and Processing of $\mathrm{Pb}-\mathrm{Zn}$ Ore. Journal of International Environmental Application \& Science. 2016; 11(2): 166-169.

5. Kadriu S, Sadiku M, Kelmendi M, Mulliqi I, Aliu M, Hyseni A. Scale of pollutions with heavy metals in water and sediment of River Ibër from landfill in Kelmend, Kosovo. Mining Science. 2019; 26: 147155.

6. Schmitt O J. Skënderbeu. Përkthimi në shqip me ndihmën Swiss Agency for Development and Cooperation SDC. Natyra. K \& B Tiranë. 2009; 1-583.

7. Emmanuel AY, Jerry CS, Dzigbodi DA. Review of environmental and health impacts of mining in Ghana. Journal of Health and Pollution. 2018; 8(17): 43-52.

8. Leppänen JJ, Weckström J, \& Korhola A. Multiple mining impacts induce widespread changes in ecosystem dynamics in a boreal lake. Scientific Reports 7, Article number: 10581. 2017.

9. Wang QG, Dai WN, Zhao XH, Ding F, Li SB, Zhao Y. Numerical model of thermal discharge from Laibin power plant based on Mike 21. Research of Environmental Sciences. 2009; 22(3): 332-336.

10. Wang JQ, Zhong Z, Wu J. Steam water quality models and its development trend. Journal of Anhui Normal University (Natural Science). 2004; 27(3): 243-247.

11. Obropta CC, Niazi M, Kardos JS. Application of an environmental decision support system to a water quality trading program affected by surface water diversions. Environmental Management. 2008; 42(6):946-956.

12. Cao XJ, Zhang H. Commentary on study of surface water quality model. JournaI of Water Resources and ArchitecturaI Engineering. 2006; 4(4): 18-21.

13. Mustapha MK, Omotosho JS. An assessment of the PhysicoChemical properties of Moro Lake, Kwara State, Nigeria. African Journal of Applied Zoology and Environmental Biology. 2005; 7:7377.

14. Sangpal RR. Kulkarni UD, Nandurkar YM. An assessment of the physicchemical properties to study the pollution potential of Ujjani Reservoir, Solapur District, India. ARPN Journal of Agricultural and Biological Science. 2011; 6(3): 34 - 38

15. Murangan AS, Prabaharan C. Fish diversity in relation to physicochemical characteristics of Kamala basin of Darbhanga District, Bihar, India. International Journal of Pharmaceutical and Biolgical Archives.2012; 3(1): 211-217.

16. Deepak S, Singh NU. The Relationship between Physico-chemical Characteristics and Fish Production of Mod sagar Reservoir of Jhabua District, MP, India. Research Journal of Recent Sciences, 2014; 3: 82-86.
17. Mbalassa M, Bagalwa JJM , Nshombo M, Kateyo EM. Assessment of physicochemical parameters in relation with fish ecology in Ishasha River and Lake Edward, Albertine Rift Valley, East Africa. International Journal of Current Microbiology and Applied Sciences 2014; 3(6): 230-244.

18. Kadriu S, Malollari I, Beqiri L, Aliu M, Sadiku M, Baruti B, Kelmendi M. Presence of heavy metals in water and sediment of rivers Trepca and Sitnica. Journal of Environmental Protection and Ecology JEPE. 2017; 18(1): 10-21

19. ISO 5667-6:2014 Water quality — Sampling — Part 6: Guidance on sampling of rivers and streams.

20. ISO 5667-1:2006 Water quality — Sampling — Part 1: Guidance on the design of sampling programmes and sampling techniques.

21. ISO 5667-3: 2012. Water quality -- Sampling -- Part 3: Preservation and handling of water samples.

22. Wattage P, Soussan J. Incorporating environmental value and externality in project evaluation as a sustainability indicator to evaluate Bangladesh water development. Water Resour Manag. 2003; 17(6):429-446.

23. Administrative Instruction MESP-No. 16/2017 on Classification of Surface Water Bodies, was approve in the Government of the Republic of Kosovo with the decision no.6526/17. 2017 Aug. 